\title{
Performing Maps and Masculinity in Irrigation Planning in Nepal
}

Why Modernization Myths Live on in Spite of Professional Reflexivity

Janwillem Liebrand

\section{CpenEdition}

\section{Journals}

Electronic version

URL: http://journals.openedition.org/anthropodev/603

DOI: 10.4000/anthropodev.603

ISSN: 2553-1719

Publisher

APAD - Association pour l'anthropologie du changement social et du développement

Printed version

Date of publication: 1 December 2017

Number of pages: 150-185

ISBN: 979-10-93476-05-6

ISSN: 2276-2019

\section{Electronic reference}

Janwillem Liebrand, « Performing Maps and Masculinity in Irrigation Planning in Nepal », Anthropologie \& développement [Online], 46-47 | 2017, Online since 01 June 2018, connection on 30 April 2019. URL http://journals.openedition.org/anthropodev/603 ; DOI : 10.4000/anthropodev.603

La revue Anthropologie \& développement est mise à disposition selon les termes de la Licence Creative Commons Attribution 4.0 International. 


\title{
Performing Maps and Masculinity in Irrigation Planning in Nepal
}

\author{
Why Modernization Myths Live on in Spite of \\ Professional Reflexivity
}

\author{
Janwillem Liebrand
}

Cet article explore pourquoi le mythe de la modernisation persiste malgré une réflexivité professionnelle à propos de l'activité de planification. L'article a pour objet la planification de l'irrigation depuis les années 1950 dans le district de Chitwan au Népal. L'analyse porte sur les convictions modernistes et la réflexivité professionnelle et met en avant l'usage d'artefacts tels que les cartes et la "masculinité » d'une culture professionnelle, celle de l'irrigation. L'analyse suggère que les usages de cartes dans la planification de l'irrigation trouvent leur utilité pour les professionnels parce qu'ils permettent de normaliser une association entre ingénieurs (hommes), l'idée de supériorité, et des revendications sur la prééminence de la technologie et de la science en ce qui concerne les savoirs sur l'eau. Ainsi, les cartes sont performatives car elles encadrent et normalisent des associations entre convictions modernisatrices, experts (hommes) et "masculinité » dans le secteur de l'irrigation.

This article explores why modernization myths live on in spite of professional reflexivity in planned development. The focus is on irrigation planning in Chitwan District, Nepal, from the 1950s onwards. In analyzing modernist convictions and professional reflexivity in planned development, the analysis takes into account the use of expert knowledge artefacts, such as maps, and a professional culture of 'masculinity' in irrigation. The analysis suggests that uses of maps in irrigation planning are meaningful for professionals, because they help normalize an association in water knowledge between (male) engineers, ideas of supremacy, and claims of technology and scientific authority. In this capacity, maps can be considered to 'perform', subconsciously, channelling professional reflexivity and normalizing associations between modernist convictions, (male) experts and 'masculinity' in irrigation. 


\section{Introduction}

Scholars in development studies have more than once resorted to the metaphor of 'modernization myths' to criticize a conviction among development planners that the transfer of technology is bringing progress (Scott, 1998; De Rivero, 2001; Mies, 2014). The source of their critique has characteristically been anthropology and feminist-based case studies, documenting people's lives in the field to reveal the complexities and show how planned interventions are deployed in the field. Yet, in spite of this critique, a question - 'what does it deliver' - continues to guide most discussions on development. In this article, I seek to understand why modernist convictions are still going strong in planned development, despite carefully articulated criticism, based on overwhelming case study material. More specifically, I focus on the role of experts themselves, being especially interested in processes of professional reflexivity.

State irrigation development in Nepal represents a good example for such analysis. Professionals in irrigation planning in Nepal, notably engineers, from the 1950s onwards, have promoted technologies and managerial models based on ideals of universal science and technical knowledge (Dhungel and Pun, 2009; Liebrand and Udas, 2017). Right from the 1970s, anthropologists and other development scholars have exposed the modernist assumptions that underpin these models, triggering professional reflexivity, especially among engineers (International Irrigation Management Institute (IIMI) and Water Energy Commission Secretariat (WECS), 1987; Martin and Yoder, 1988; Pradhan, 1989). In the 1970s, 1980s and 1990s, amidst new economic, social and environmental concerns, planning experts - amongst which anthropologists and sociologists - designed new models for irrigation development, aiming to promote more 'user friendly', 'gender sensitive' and 'environmentally safe' interventions (Department of Irrigation, 2003). For these new models, knowledge of (Western) social sciences have been a source of inspiration (Coward et al., 1982; Shivakoti and Ostrom, 2002).

\footnotetext{
${ }^{1}$ The comments of the editors of the special issue and two anonymous reviewers are gratefully acknowledged.
} 
Yet, in spite of the reflections and changes and the use of social sciences knowledge in planning, or perhaps because of it, development scholars argue that interventions in Nepal continue to be understood in the scope of an 'old' story of irrigation modernization (Shrestha, 2009; Singh et al., 2014; Gyawali et al., 2017).

One dominant reading for the continued existence of modernist thinking in development planning is that modernist ideals have strong political appeal. They find their way into state planning time and time again under the pressure of politicians, administrators and donor officials who make promises and want to 'deliver' (Shrestha, 2009). Feminist scholars, in this regard, hint at the links between modernization, patriarchy and male power (Mies, 2014). They argue that relationships between the notions of men, masculinity and power are being cultivated in practices of promoting science and technology, and they identify planned development as one domain in society in which power and 'being professional' is validated with status and maleness (being a male/boy/man) (according to Whitehead, 2002). Another explanation and one that has received much less attention than analyses on politics and (gender-related) power in development, is that modernist convictions thrive in development planning, because experts themselves habitually - and largely subconsciously - normalize them in practices of knowledge production and acts of professional reflexivity.

To analyze this idea and pay attention to a feminist critique on 'masculinity' in modernist thinking, I am 'studying up' the making of irrigation knowledge in Nepal, taking inspiration from anthropologist Laura Nader (1972) and feminist scholar Sandra Harding (2004). Nader (op. cit.: 288) originally defined studying up as a research strategy to address 'the facelessness' of a bureaucratic society and the major institutions that affect everyday lives. Harding interprets studying up as doing research from the standpoint of marginalized people in society (women, people of colour, lower classes, etc.), taking their place in society into consideration and questioning (scientific) 'objectivity' and 'truth'. To analyze processes of reflexivity, I use studying up to put a face on the network and culture of irrigation experts and focus on some of the means and conceptual frameworks they create to promote science and technology. 
Some of these means are self-evident: expert knowledge artefacts. These can be policy documents, databases, and public presentations or, for instance, sets of statistics, tests, techniques and calculations. Some of the 'faces' of the network and culture of irrigation experts are also evident. In the domain of irrigation, professionals tend to be men, especially (civil) engineers, and Nepal is no exception in this regard (Liebrand and Udas, 2017). Not surprisingly, feminist scholars have identified the irrigation profession as an example of a man's world in development, tied to the state bureaucracy and a culture of engineering (Lynch, 1993; Laurie, 2005; Zwarteveen, 2011; Ongsakul et al., 2012). In order to explore how, within the context of a particular 'masculine' expert culture, certain professional means shape knowledge production and professional reflexivity, I focus on maps, treating them as a special case of knowledge artefacts. More specifically, I focus on a set of maps of Chitwan District in Nepal, an area that was first targeted by the state for planned development in the 1950 s.

Theory and method: Analyzing maps and professional reflexivity

For this analysis, I rely on cultural performance theory as it was first developed by the anthropologist Victor Turner (Turner and Bruner, 1986; Turner, 1987; Schechner, 2006; John, 2008). Using this theory means that I conceptualize professions as cultures and the uses of expert knowledge artefacts as cultural practices. Cultural performance, in analogy with ritual or theatrical performance, can be defined as follows: showing off, behaving as expected, acting according to social norms or even underlining actions for those watching (Schechner, 2006). From this point of view, professional performance is more than just an outcome of merit or innate technical skills and knowledge but also one of a capacity to perform 'on stage' and take one's place among peers (Hilgartner, 2000).

Turner was interested in processes of cultural reflexivity and he argued that "cultures are most fully expressed and made conscious of themselves in their ritual or theatrical performances" (Turner in 1980, cited in Schechner, 2006: 19). He was intrigued by the capacity of rituals to channel the reflexivity of those undergoing them. First, he argued, ritual performances express or symbolize meaning and emotion of culture and experience (Turner and Bruner, 1986). For instance, offering foods and 
items at a shrine to please the gods is a clear expression of certain beliefs and norms in society. Second, he argued that rituals have the capacity to reconstruct culture, dramatizing and casting the present in relation to a hypothetical past and an anticipated future. For instance, people perform offerings at a shrine as they have been taught, and in doing so, they recreate the performance and make it into a new culture; they do so in the present because they believe the gods brought misfortune in the (hypothetical) past and will bring them prosperity in the (anticipated) future. Seen from this angle, people come to 'make' their culture through ritual, or scripted and staged behaviour - behaviour that has no single author and is denoted by aesthetic conventions, traditions and styles of decorum.

Turner's ideas have come to be widely used in studies on cultural performance (McKenzie, 2001; Schechner, 2006; John, 2008), including in irrigation studies (Rap, 2006). The idea that expert knowledge artefacts can 'perform' has been explored, for instance, in the use of survey results (Law, 2009), the construction of databases (Turnhout and Boonman-Berson, 2011) and the presentation of numbers on irrigation development (Zwarteveen and Liebrand, 2015). Applying the theory to a map-study promises to be especially interesting, because maps can be considered particularly powerful artefacts in terms of theatrical performance. Maps summarize facts, showing what can be achieved by planners and engineers; by their simplicity and uniformity, maps provide a visually rich snapshot of a certain reality in a manner words or numbers can rarely achieve (Reuss, 2008). Klingensmith (2007), for instance, observes in his study on dams and river planning in India, that maps are not just made and imagined by their 'authors' but also by their 'readers', who re-make and reimage as they read (becoming authors in turn). In other words, maps are powerful 'performers': they describe a certain reality and simultaneously breathe new life into the interpretations they show.

In his studies on cultural reflexivity, Turner paid specific attention to 'liminality'. He defined it as the margin or transition phase of rituals (Turner and Turner, 1978). He observed that participants in religious rituals (such as young boys taken into the forest for initiation rites) associated their involvement with ambiguity, disorientation and an intensive flow of experience. He argued that this 'flow' marks a condition of transition and 
potentiality in people, representing a disruption of experience that has a beginning (boyhood), a middle (becoming a man) and an ending (manhood). In other words, in liminality, a culture is 'made' aware of itself, but Turner observed that participants engaged in the ritual have a 'liminal awareness' of this process. Put differently, they are not fully conscious of what meanings and associations are precisely attached to it (Martin, 2001).

Liminality has proven to be a useful concept for studying peoples' practices and experiences that are conceptualized as 'bracketed' yet connected to everyday life (Howard-Grenville et al., 2011). It offers an explanation of why modernist convictions continue to thrive in irrigation planning in spite of professional reflexivity; it is because professionals subconsciously reproduce them in the act of using maps. Because of their visual appeal, maps can be conceptualized as particularly bracketed disruptions of professional experience in planned development, marked (hypothetically speaking) by a beginning (a primitive Nepal), a middle (planning development for Nepal) and an ending (a modern Nepal). The concept also offers an explanation of how relationships between men, masculinity and power are mobilized among irrigation professionals (Martin, 2001); because ideas of supremacy and symbolic notions of male power can be attached to and normalized in the use of maps in irrigation planning. In other words, I intend to make a proposition for the case that modernist convictions are still thriving in irrigation planning, because of the signification of 'masculinity' being culturally attached to them, and because irrigation experts themselves mobilize these convictions and meanings in a state of liminal awareness in the act of using knowledge artefacts.

In this article, I wish to underline that I am primarily concerned with studying the cultural dynamics of professional reflexivity in irrigation planning. The question is not whether maps are true or false. With Mark Monmonier (1996), I acknowledge that good maps need to lie. Every good map embodies a cartographic paradox: a map must offer a selective, incomplete view of reality to avoid hiding critical information. Nor is it a question of associating liminal awareness with the implication of false consciousness. Studying the cultural dynamics of how irrigation experts think fits uneasily into monolithic notions of dominance, resistance and hegemonic relations (Mosse, 2004). Neither is the question about the idea 
that women experts in irrigation make and read maps differently than men. I reject essentialist ideas of masculinity and femininity. I am aware that my conceptualization of the irrigation profession as a 'masculine' expert culture touches directly on contentious questions at the heart of the masculinity debate in feminist scholarship (e.g. why label something as 'masculine'?; how is it possible to establish an association as 'masculine'?) (Whitehead, 2002; Connell, 2005). I use 'masculinity' here to conceptualize how maps help irrigation experts to create credible voices and identities for themselves and acknowledge that those voices and identities tend to be associated with male engineers and, symbolically, with ideas of control and domination as well as truth and objectivity in science.

To study up professional culture in irrigation and the performative role of maps in it, I rely on documentation research and a handful of interviews with senior irrigation professionals and development planners in Nepal, as well as a critical reading of the maps themselves. The focus is on a selection of five maps of the Chitwan District. This selection can be considered to show the state of irrigation planning in Nepal from the 1950s onwards. The maps were used in policy reports and public peer presentations by government officials and researchers in Nepal. In critically reading the maps, I analyze the details of the maps (what is shown and what is not), seeking to understand what professional experience, in Turner's words, they rely upon and invoke. To analyze the professional network in which the maps were meaningful, I trace some of the key actors of the maps (their authors and readers), relying on documentation research and seven in-depth interviews with irrigation experts in Nepal (all male engineers), conducted between 2009 and 2011 as part of PhD research. Among these experts was Huta Ram Baidya (1921-2013), for instance, who was known as the first agricultural engineer in Nepal.

First follows a brief description of the professional network and culture of irrigation planning in Nepal, highlighting its associations with men, masculinity and engineering. The rest of the article presents an analysis of the maps, highlighting their authors and readers, and how they have helped shaping professional reflexivity. 


\section{Professional network and culture of irrigation planning in Nepal}

In Nepal, national development policies started in the 1950s. With the collapse of the Rana regime in 1951, the new government of Nepal opened the country to foreign aid and made a proclaimed effort to develop Nepal into a modern state. The introduction of modern agriculture and irrigation technology was a key focus area, discussed in depth and breadth at Nepal's first conference on agriculture in 1958 (Dahal, 1997). In these discussions, India was an example for Nepal. Indian advisors assisted Nepal with the design of a new government structure (Shrestha, 2001) and they helped, for instance, with the set-up of a Ministry of Public Works and a Canal Department in 1952 - the predecessor of today's Department of Irrigation (DOI). This department was mandated with the construction of canal works in the country for irrigation supply for agriculture and on Nepal's request, a retired male irrigation officer from the Punjab acted as the first chief engineer (Liebrand and Udas, 2017).

The introduction of state planning and a new engineering knowledge network in Nepal and an associated culture of male professionals in irrigation thus coincided with the start of modern development in the 1950s, but its historical associations are older. They can be traced back to the British colonial administrative system in India, as illustrated by the first civil engineering college in British India, Roorkee College, which was established in 1847. As Zwarteveen (2011) writes, this type of colonial college was an exclusively elite and masculine domain, functioning as sites for the promotion of ideals of Victorian manliness in British India. They were places where associations between athleticism, militarism and the performance of professional authority, race, and manhood, were forged in a colonial context between British and Indian male students as well as between male engineers of different rank. Such an association of men, masculinity and engineering continues to characterize the irrigation profession in South Asia, including Nepal. For example, in 2011, the DOI in Nepal had 447 officers as core personnel, among them only 20 female officers (4\%), out of which 335 officers (79\%) were engineers by education, predominantly civil engineers who had gone to India for their education. In total, 9 out of 13 Directors General of the DOI (all men), between 1956 and 
2013, were trained at Indian engineering colleges (Liebrand and Udas, 2017).

In Nepal, as elsewhere in South Asia, state irrigation planning has thus always been the domain of men and 'male' power, being shaped by an 'Indian' network and a professional culture of engineering. The Chitwan district illustrates what this network and culture can achieve. The first water-resource studies were conducted in the 1950s, and modern irrigation farming was introduced in Chitwan through the construction of a pilot project, a medium-sized canal system. Since then, Chitwan has continuously benefitted from irrigation infrastructure development (see Figure 1 for an overview). As a result, by $2010,29,623$ ha or $70 \%$ of the total cultivated area in Chitwan was 'developed' for irrigation according to the statistics of the DOI, much more than the national average of $46 \%$. In total, about $37 \%$ of the developed irrigated area was covered by DOI canal projects; $52 \%$ by rehabilitated and so-called farmer-managed irrigation systems (FMIS) and $11 \%$ supplied by tube wells.

\section{How maps perform}

The analysis of the maps is divided into four sections, covering the development of state irrigation planning in Chitwan District: the Rapti Valley Development Project (1956-1960); the Chitwan Valley Development Project (1972-1990); the East Rapti Irrigation Project (1992-1996) and the Trishuli-Lothar Diversion Project (proposed in 2010). 


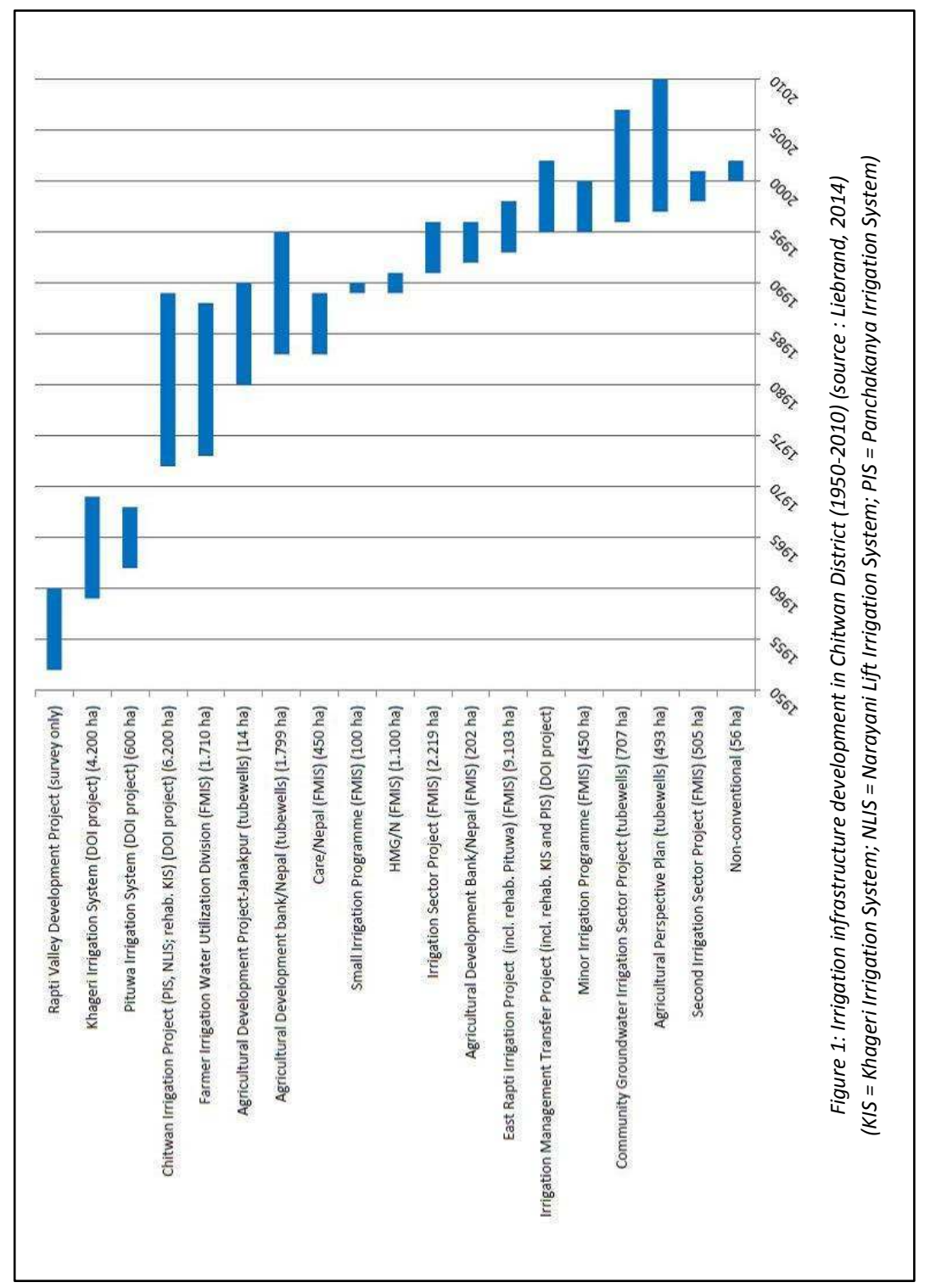




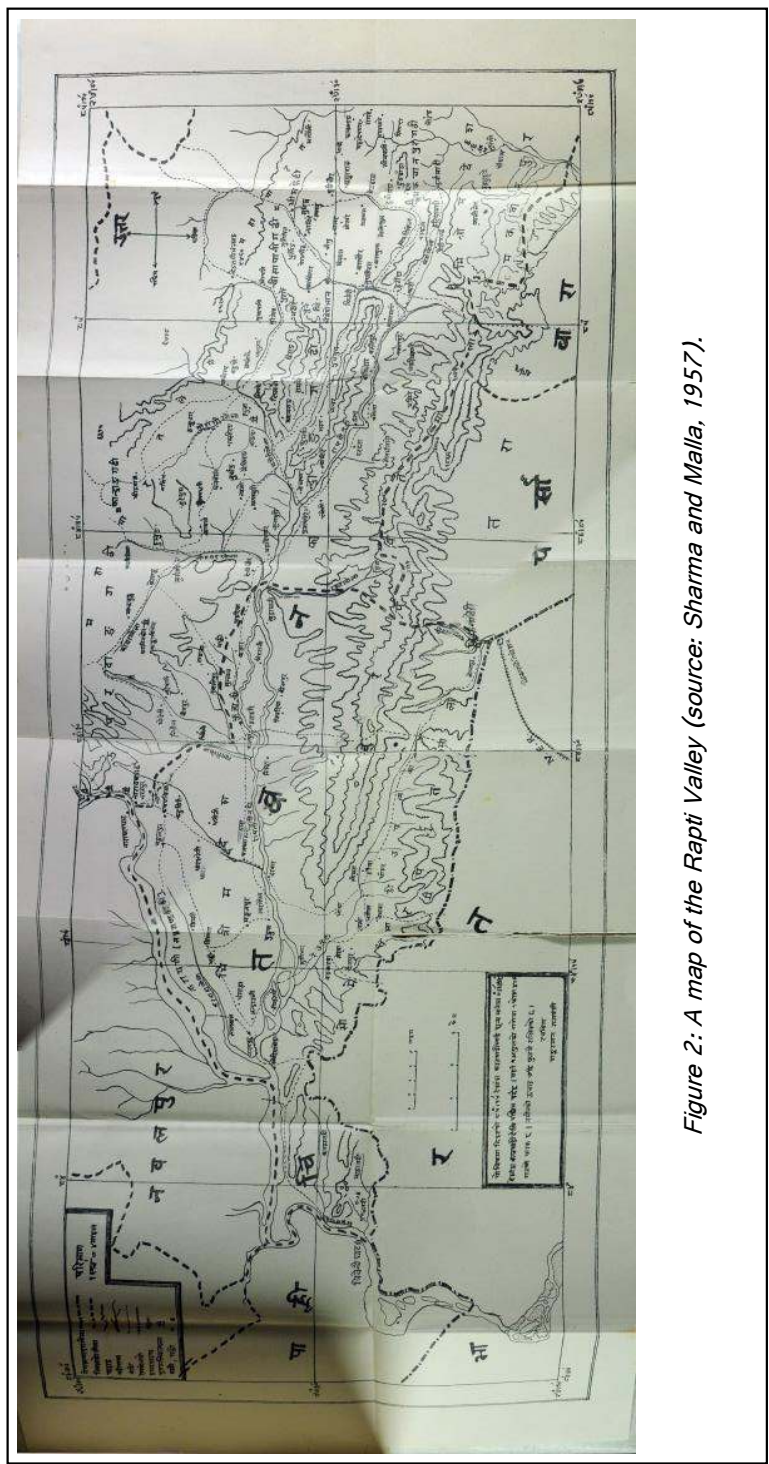




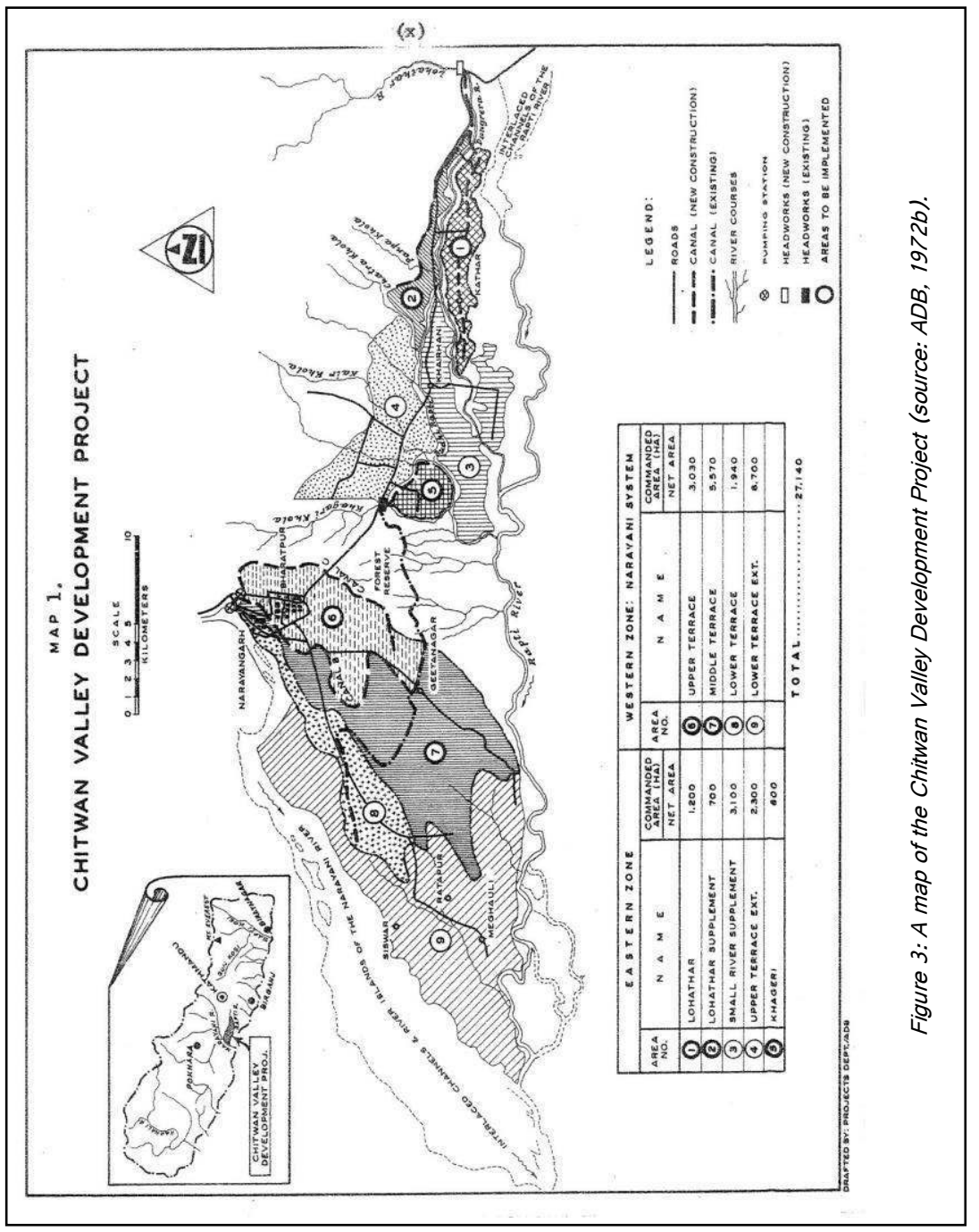




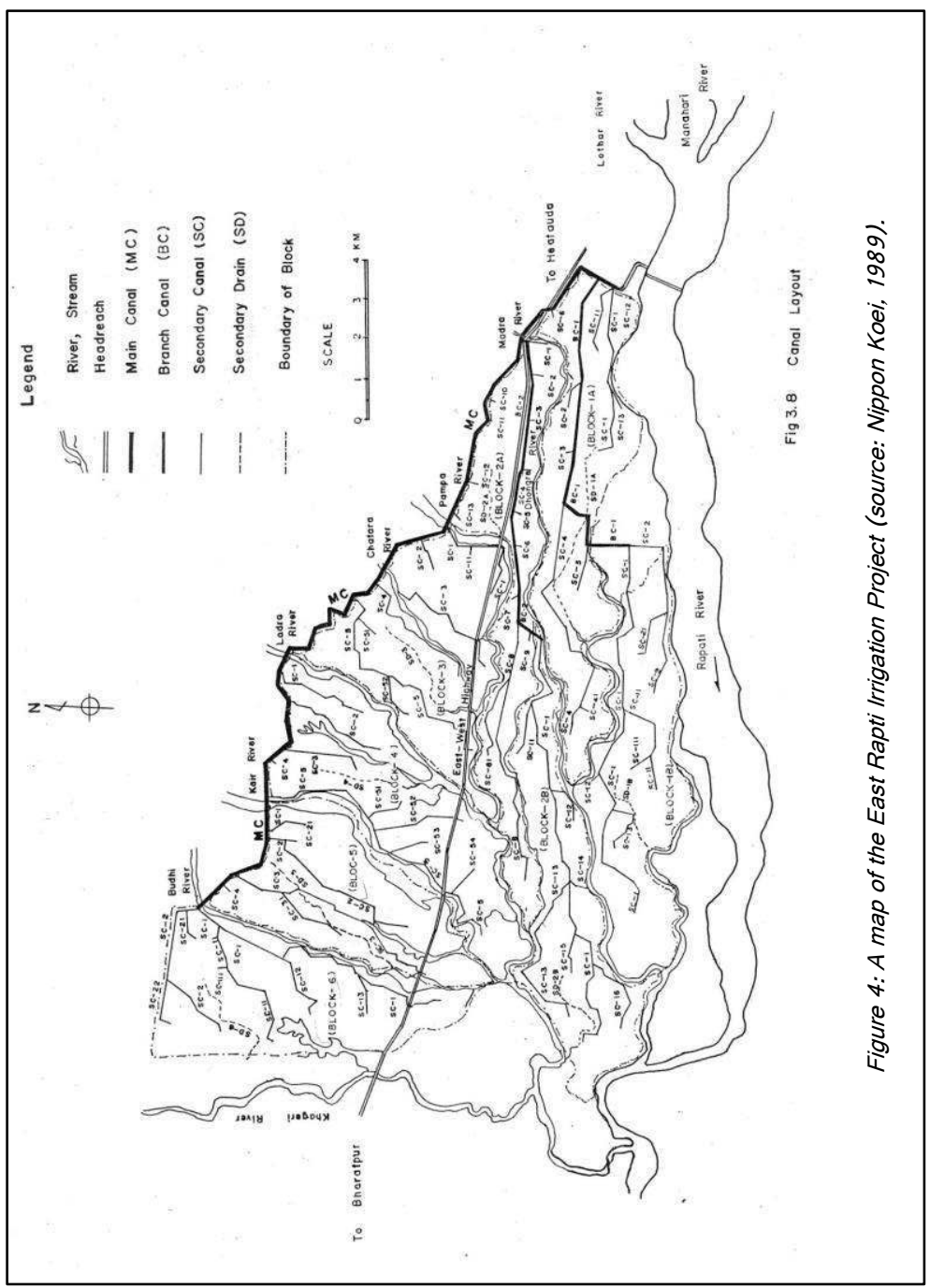




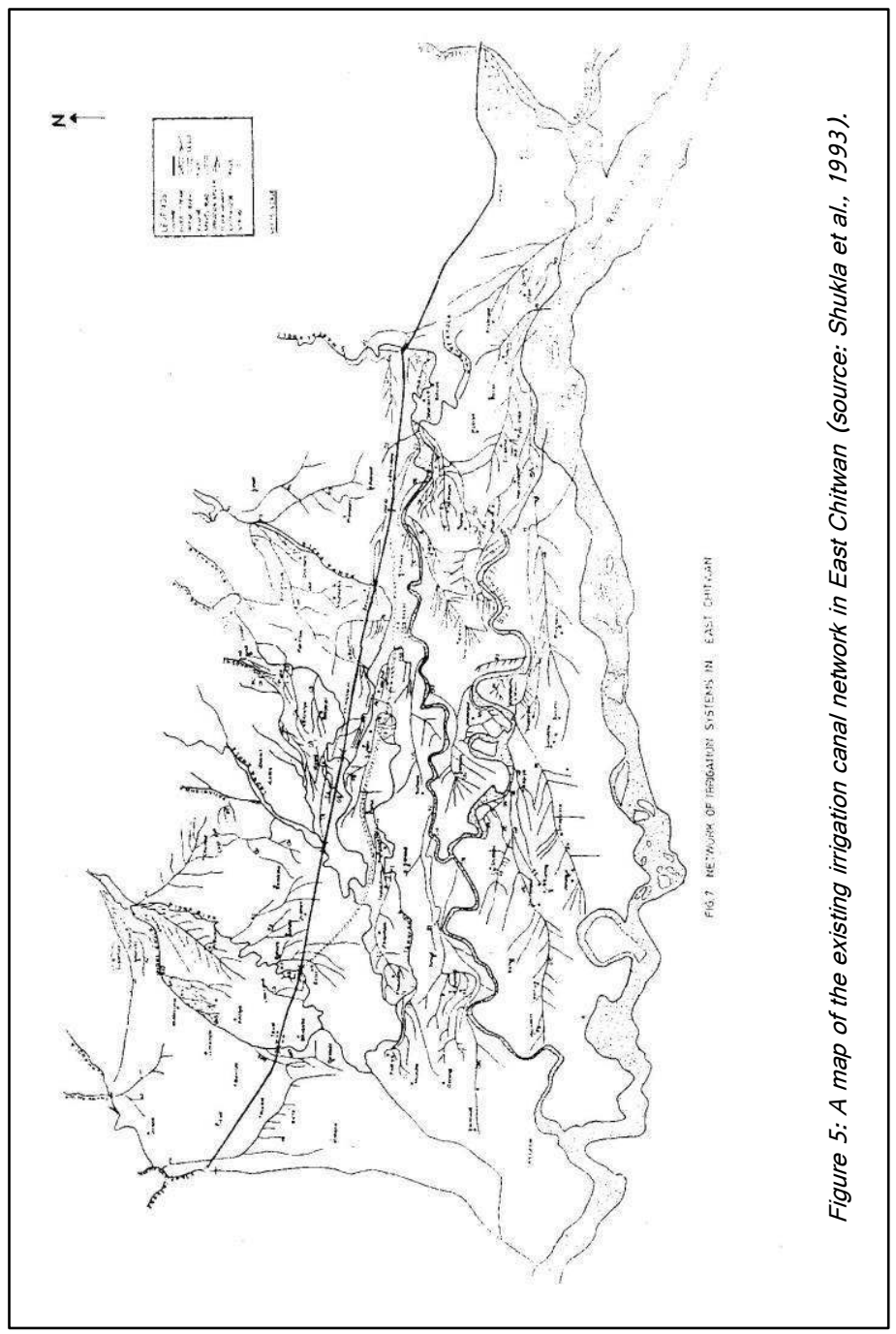




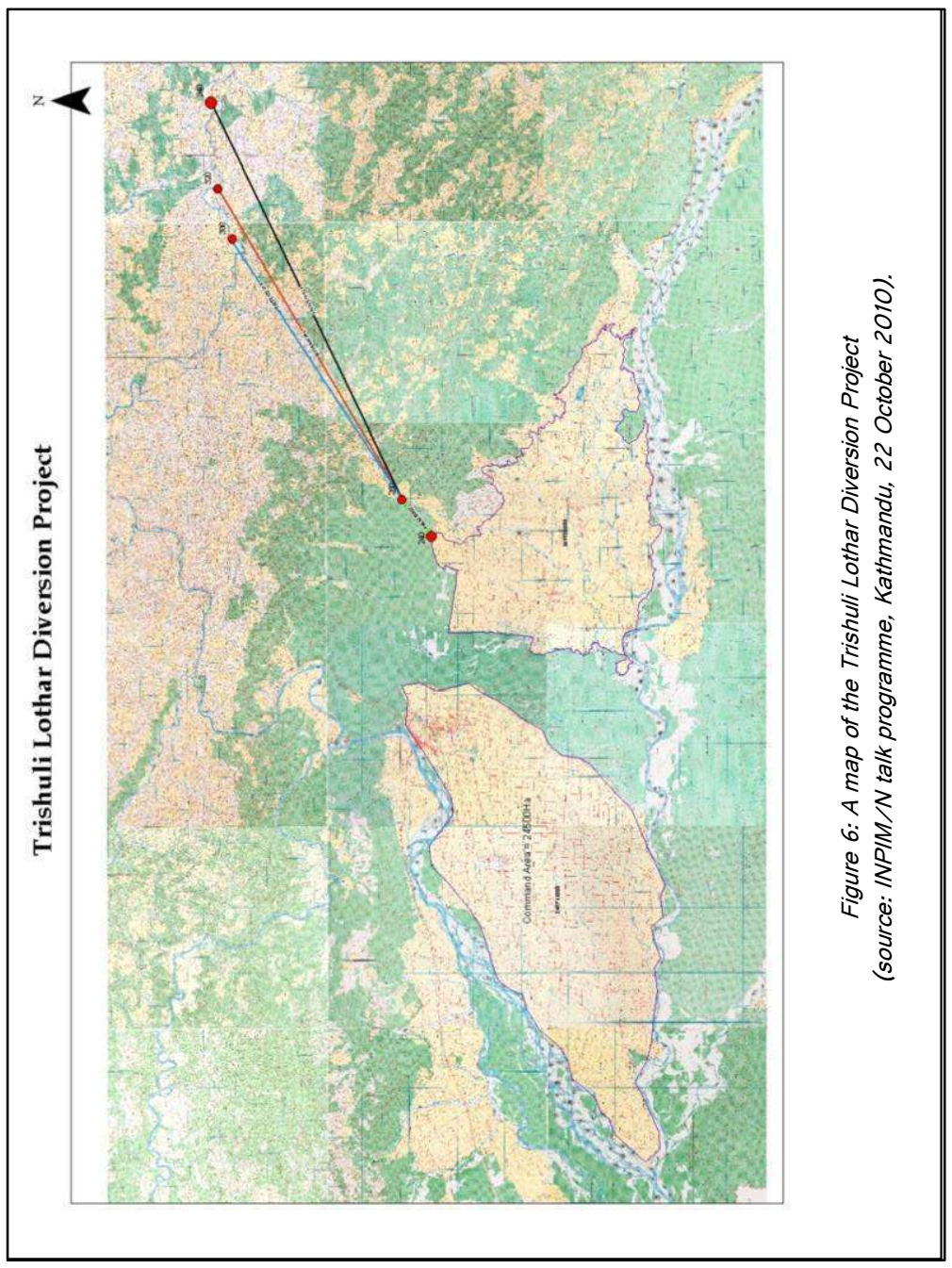




\section{The Rapti Valley Development Project}

The first map (see Figure 2) is taken from a study called 'Rapti Upatyaka', which means Rapti Valley, published in 1957 (Sharma and Malla, 1957). Chitwan District largely overlaps with the Rapti (River) Valley. One of the authors was Krishna Bam Malla, an agriculturalist, who was then a highlevel official and co-director of the Rapti Valley Development Project (RVDP). The document was meant to inform policy makers and the public for the first time in Nepal about the potential for planned development ${ }^{2}$. The RVDP was the first and most important state modernization project in the $1950 \mathrm{~s}^{3}$. As the name suggests, the RVDP was conceived as a river valley project, modelled after the Tennessee Valley Authority (TVA) in the US. At that time, the TVA was regarded by the West as a paradigm for world reconstruction, a model agency which showed how 'the liberal state' could meet or avert the political and social challenges of economic crisis (Klingensmith, 2007). It represented an idea about the technical and apolitical management of natural and economic resources, a scientific model of planning that would produce prosperity for all in a way that could be reconciled with 'grassroots', democratic participation - a view eloquently expressed by 'Mr TVA', as David Lilienthal was then known, in his book TVA: Democracy on the march (1953).

In Nepal, it was sardar Bhim Bahadur Pandey who travelled to the US in December 1946 to study and observe the TVA ${ }^{4}$. Mr Pandey can be considered one of the first modern planners in Nepal. In the 1950s, he became the secretary of Planning and Development. In his book, Tyas Bakhatko Nepal (Nepal at that time), he mentioned that his visit was specifically meant to study the TVA because it was considered an international model for an undeveloped region like Nepal, to learn about all aspects of development (Pandey, 1988, vol. 4: 6). He felt that something similar could be done in Nepal, and in 1948 he identified Chitwan - an area that was known to the elite in Kathmandu for hunting expeditions - to try

\footnotetext{
${ }^{2}$ I thank the MPP library in Kathmandu for making this rare document available.

${ }^{3}$ Other big projects in the Tarai were essentially executed by the Indian government.

${ }^{4}$ Sardar was an honorary title of a high administrator under the Ranas.
} 
development, conceived in the image of the TVA. In 1952, Mr Pandey toured Nepal with Paul Rose, then the first director of the United States Operation Mission (USOM), and he suggested starting a project in the Rapti valley ${ }^{5}$. This idea appealed to Western experts of the USOM, the FAO and the United Nations (Rauch, 1954; UN, 1961). In their view, poverty was based on an over-population in the hills and an under-utilization of natural resources in the Tarai, something that could be remedied through technology ${ }^{6}$. The 'empty' space of Chitwan represented an ideal place for them to promote a 'TVA in Nepal'.

In this new professional experience of development and cultural exchange of experts, the report prepared by Mr Malla was a powerful expert knowledge artefact, especially a 16-pages, folded map that was put as an annex in the report (see Figure 2). As can be seen, the main feature of it is that it represents the Rapti valley as a watershed and a 'state space' in Scott's (1998) words, showing district boundaries and the national border with India in the south. It indicates the Rapti River system and elevation lines. The map also shows roads and names of settlements, but the visual effect is mainly that Chitwan is presented, at glance, as part of the national space, as being empty and underutilized and hence, suitable for planned development. I am sure that such a map enabled Nepalese and Western men to participate in the same heroic and grandiose interpretations of planned development, creating a new cultural unity among themselves. For example, one of the readers of the map was Huta Ram Baidya, who visited Chitwan and worked for the Department of Agriculture at that time. In interviews, he recalled an FAO mission of foreign experts in 1952, who made similar watershed maps to assess the irrigation potential of the Kathmandu valley. He commented "they were most of the time right", even though he admitted that their work was largely based on estimations and guesswork in the absence of any reliable data $^{7}$. Such memories expose an admiration (and identification) with

\footnotetext{
${ }^{5}$ I thank Tom Robertson, Worchester Polytechnic, for sharing this information with me.

${ }^{6}$ The Tarai is the land at the foothills of the Himalaya.

${ }^{7}$ Interview with Huta Ram Baidya, 29 December 2009.
} 
science and technology experts, and a new engineering identity associated with it.

The RVDP was eventually implemented between 1956 and 1960, but ended up doing little on irrigation and improved use of river resources. A first water resources assessment proved difficult and the most fertile and productive parts of the valley, where river conditions were close to perennial, were already occupied by Tharu agriculturalists, an indigenous community in the Tarai. In fact, only the driest parts of the districts were 'empty' and 'available' for new settlement. The project focussed on malaria eradication and the clearance and settlement of land for hill migrants, mainly in the west of the district. In these terms, the project was more or less successful. In 1956, $71 \%$ of the children in the district had been infected with malaria, but in 1964, the area was free of the disease and the DDT spraying method was reproduced elsewhere in the Tarai (Müller-Böker, 1999). In regard to land, by $1960,27,759$ ha of land (66\% of the presently cultivated area in the district) had been distributed to 5,233 families, but much of it had been acquired by Kathmandu-based state elites rather than by landless peasants, and other land was settled 'unplanned' by migrants on their own initiative (Ohja, 1983).

The RVDP provided Western and Nepalese experts with a critical first experience of river valley development in Nepal. The project was a nursery for planners and engineers in Nepal to test new ideas on modernization and it planted the seeds of irrigation planning. These ideas culminated in the first 'Master plan for irrigation development in Nepal' (His Majesty's Government of Nepal (HMG), 1970), a collaboration between international experts, and Nepalese and Indian engineers. The plan envisioned a complete redesign of Nepal, technically, politically and culturally, especially of the Tarai which was completely planned for state-controlled irrigation. As the plan states:

"The future irrigation in Nepal should be year-round irrigation by which two or more crops a year can be obtained. To this effect, the ample water resources of the country should be fully utilized. New irrigation projects should be planned to include not only the main and secondary canals, but also the tertiary and smaller canals [...], complete drainage system, network of farm roads, readjustment of 
lands, flood prevention works, communication networks, irrigated farmers' centre etc." (HMG, 1970: S.2).

To express this ambition, the study included a map of Nepal, dividing the Tarai in twelve 'irrigation blocks' ${ }^{\prime}$.

\section{The Chitwan Valley Development Project}

One of these irrigation blocks was Chitwan valley, for an area of 24,000 ha and the government of Nepal awarded it the highest priority for implementation because it was considered a suitable pilot project. As the irrigation master plan noted:

"As the year-round irrigation farming should be a new target for agricultural development in Nepal, it is necessary to establish one or more model projects in which the engineers, technicians and leading farmers are to be trained first. In this context, the Chituan project [...] should be taken up and implemented as the pilot [project] to realize and practice the epochal development of agriculture and irrigation in this country" (emphasis added) (HMG, 1970: S.3).

The government of Nepal requested the Asian Development Bank (ADB) in 1971 for assistance with the implementation of the project. One year later, in 1972, consultants from Germany (Agrar- und Hydrotechnik $\mathrm{GMBH}$ ), contracted by the $A D B$, started their studies for a scheme that came to be known as the Chitwan Valley Development Project (CVDP). In line with the irrigation master plan, the consultants envisaged a radical transformation of culture and society in Chitwan, based on year-round irrigation. This was not an easy job, mainly because available water resources in Chitwan were then perceived as unfavourable and insufficient for year-round gravity irrigation (ADB, 1972a).

Eventually, the German consultants made a plan for the CVDP for a total area of 14,000 ha, consisting of various irrigation projects. Over $80 \%$ of the total budget (exceeding USD 19.5 million) was allocated to civil engineering works and the project legitimized the expansion of a national irrigation agency (the DOI). To show policy makers what could be done by

${ }^{8}$ This map is not presented here. It can be seen in Zwarteveen and Liebrand (2015: 268). 
engineers, the main report of the design study included a map showing key details of the project (see Figure 3 ). As can be seen, it shows the location of the project within the country of Nepal, the main canals and command areas as well as the main river systems. A defining feature of the map is that it clearly shows a full utilization of available resources, especially land resources, highlighted by different shades and patterns for all the projects. I like to think that this map expressed the fulfilment of professional aspirations as they were first pictured with the RVDP, especially for a first generation of Nepalese engineers. This was the heyday of international irrigation infrastructure development when the word 'engineer' meant 'man' taming nature, controlling technology and creating new flows of water on underutilized lands (HMG, 1985). For example, two of the mapreaders were Nanda Kishore Agrawal and Bubanesh Kumar Pradhan, the latter acting as Director General of the DOI at that time. These pioneer engineers are honored to this day in the irrigation engineering community in Nepal as the 'Irrigation Man' and the 'Water Emperor' (jal samrat) respectively. I can imagine that the detailed design map of the CVDP, during discussion of the project, enabled these men, as their heroic names suggest, to live up to the then professional norms in development and be seen as equals to foreign irrigation experts.

The CVDP never realized the intended development of agriculture and irrigation. Problems were there from the start: delayed negotiations with consultants, financial negotiation problems with contractors and devaluation of the US dollar - to name a few. However, the real shock came in 1983 and 1984 when the pumps of one of the biggest projects, the Narayani Lift Irrigation System, were operated for the first time. Due to the load of sediments in suspension in the Narayani River during the monsoon, the canal system clogged up with silt and the pumps broke down. By early 1985 , more than $30,000 \mathrm{~m}^{3}$ of silt had to be removed - the capacity of the first stretch of main canal was just $7,000 \mathrm{~m}^{3}$ - and pump parts were

\footnotetext{
${ }^{9} \mathrm{Mr}$ Agrawal was commemorated in an e-mail circulation (1, 9 and 11 February 2012) among $\mathrm{DOI}$ engineers as the Irrigation Man and "a statesman of our surface irrigation systems in Nepal". Mr Pradhan (interview 8 August 2011), retired but still active, was dubbed the Water Emperor by Jhal Nath Khanal, a leading politician in the country. He also earned a reputation as the "baron of the irrigation sector" (Dhungel and Pun, 2009: 296).
} 
replaced (Jyoti, 1985; Rothwell, 1985). The problem was difficult to solve. A new study calculated that the system, when operating at full potential, had to cope with a silt-load of $57,000 \mathrm{~m}^{3}$ annually. Remedial works were proposed (sand trap, intake redesign, pump replacement, sludge pump installation) but they proved inadequate, especially because the system had to face a monumental electricity bill (ADB, 1972b; WECS, 1995). In other words, the operation costs were too high for the government and the proposed command area was never irrigated all year-round.

\section{The East Rapti Irrigation Project}

The CVDP also experienced setbacks with another project, the Lothar scheme in east Chitwan. Implementation was repeatedly delayed. The project was eventually included in 1986 under a new loan of the ADB for the East Rapti Irrigation Project (ERIP). A reason for the delay was "existing irrigation facilities" in the area (ADB, 1986: 6). The appraisal report for the CVDP had noted "small fragile farmer-built irrigation systems" and considered that "farmer built intakes [give] flood waters entrance to [...] farm lands with [...] erosion and [...] fragmentation of land" as a result (ADB, 1972b: 17). Therefore, it was proposed to arrange "compensation of farmers whose private schemes are going to be eliminated" (emphasis added) (ADB, 1972a: XI-1). In interviews, senior engineers explained to me that such systems had no value for them because it was then believed that, the systems could not support year-round irrigation ${ }^{10}$. In 1982, however, an English consultant engineer recommended improvement of the "intensive small irrigation systems already functioning under local management" (Adams, 1982: 1). The wording here is positive, revealing that engineering views on irrigation were changing.

The study of Adams proposed to link the farmer schemes, utilize the existing canal networks as much as possible, and supplement the systems with water from the Rapti River by means of a diversion dam. In spite of this report, the ERIP project continued to be seen by many engineers and planners as "one of the few remaining large-scale irrigation projects [in

\footnotetext{
${ }^{10}$ Interview with Madhav Belbase, 26 July 2010; Surya Bhakta Upadhya, 3 July 2011; and Bubanesh Kumar Pradhan, 8 August 2011.
} 
Nepal] that could provide [a] year-round irrigation facility" (DOI, 1990: xvii). The Japanese consultants, Nippon Koei, who were contracted for the job by the $A D B$, remained faithful to standard engineering knowledge. They designed a modern irrigation system with a dam in the Rapti River and a main canal of 24 kilometres to supply an area of 9,500 ha with a dense canal network (ADB, 1987). To demonstrate the superiority of science and technology, of civil engineering works in irrigation, and convince policy makers, the Japanese included a detailed map with the proposed canal layout in the design report (see Figure 4). As can be seen, the map shows new canals, neatly covering the full potential land area, but it does not show existing systems, creating legibility for planners who seek to construct a new and modern world order.

This time, however, the new plans coincided with a new neo-liberal aid regime and what can be dubbed the anthropological turn in irrigation knowledge. The ERIP project became a site of controversy in relation to state irrigation policy, professional expertise and engineering knowledge. The project was criticized by researchers in Nepal for its engineering focus and the neglect of existing irrigation practices in Chitwan (Khatri-Chhetri et al., 1988). This critique reflected a global trend in development in response to new principles of decentralization and cost-recovery. The criticism made by Walter Coward, for instance, then a sociologist at Cornell University in the US, was directed against national irrigation agencies and foreign donor groups, and a focus on "building things" (Coward et al., 1982). The critique was drawn from research on farmer-oriented processes in rural development, focussing on technology and communication between public agencies and farmers. Key actors in these debates were researchers of Cornell University, then a mixed group of agricultural specialists, economists, sociologists and anthropologists (Levine, 1992, 2013). In the 1980 s, these men travelled over Asia to share new insights and promote social sciences knowledge in irrigation.

Nepal and Nepalese researchers came to play a prominent role in these debates. Cornell scholars went to Nepal and they put the country on the map as an important place for research (Martin and Yoder, 1988). A topic that raised interest was the capacity of farmers in Nepal to organize their own resources in irrigation and subsequently manage systems without much state involvement, based on informal rules and collective action 
(Shivakoti and Ostrom, 2002). With this background, Chitwan became a key area for social sciences research on irrigation. In 1986, the Institute of Agricultural and Animal Science, based in Rampur, Chitwan, established an interdisciplinary study group to investigate issues in irrigation. The newly established International Irrigation Management Institute (IIMI), in which Cornell researchers were influential, provided start-up money for this group (IIMI, 1988). The study group consisted of professionals with backgrounds in agronomy, soil science, agricultural engineering, farm economy and rural extension (Khatri-Chhetri et al., 1988). The first activity of the group was an inventory study of existing irrigation systems in east Chitwan, in the area that was targeted for ERIP.

The findings were beyond expectation for the researchers. A preliminary study found eleven independent irrigation systems, providing year-round irrigation for an area of 1,200 ha. The researchers had gone to the heartland of the Tharu communities and some of the systems were over 100 years old. They documented cropping intensities that ranged up to 200 percent and the estimated yields were high, between 4.0 and 6.0 ton/ha of paddy in Spring (Khatri-Chhetri et al., 1988). The study group became very active in Nepal. It collaborated with foreign researchers, Elinor Ostrom for instance, and organized meetings with national policy actors in irrigation for discussion, notably with engineers of the DOI. For instance, in 1987, a national irrigation seminar was organized by the study group. As the proceedings state:

"The primary objective for holding the seminar was to provide a forum for [...] researchers to present the results of their work for discussion and critical review" (emphasis added) (IIMI, 1988: iii).

Ashutosh Shukla, one of the researchers and later coordinator of the group, recalled in an interview about the situation: "we [the study group] were in a very bad relationship with [the] DOI initially, because we challenged them" ${ }^{11}$.

To create a credible voice for themselves vis-à-vis engineers, the study group had to think carefully about methods to promote its work. It

${ }^{11}$ Interview with Ashutosh Shukla, 6 August 2011. 
resorted to the development of a rigorous method for data collection, and also, as mentioned in the proceedings of the seminar in 1987: "the study [was] visualized to generate lessons for future [policies]" (emphasis added) (Khatri-Chhetri et al., 1988: 3). The group started with sketches of canal networks and flow directions. The rationale is mentioned in the same proceedings:

"A sketch of the river course and the irrigation systems [is made] so that the relationship between the systems is apparent at a glance" (emphasis added) (Khatri-Chhetri et al., 1988: 6).

Over time, these sketches turned into system base-maps, and eventually, the study group produced one map for the whole of eastern Chitwan (Shukla et al., 1993) (see Figure 5). As can be seen, the map closely resembles the map of the Japanese consultants, except that it shows the existing network of irrigation canals in eastern Chitwan rather than modern, new ones. I think the work of the group had culminated in a successful exercise of counter mapping, whether deliberately or otherwise.

Mr Shukla recalled that the field knowledge of the study group, as shown in presentations, sketches and maps, had a big impact on the ERIP project. It played an important role in the process of redefining the ERIP project as a rehabilitation project for existing irrigation systems in the area. Eventually the project was executed between 1993 and 1996, assisting a total of 88 systems with canal lining and intake construction. Generally, the ERIP project provided a reflexive experience for irrigation engineers and the project helped in shaping new policies for user participation in state irrigation development in Nepal (DOI, 2003).

\section{The Trishuli Lothar Diversion Project}

The professional reflections that anthropologists, social scientists and agriculturalists had helped to initiate and the new policy directions in irrigation planning, found expression in new knowledge networks. For instance, with a view to foster debate and promote new policies of user participation in irrigation, the World Bank initiated the International Network of Participatory Irrigation Management. In Nepal, the national chapter of the network (INPIM/N) was initiated in 1997 with a first ad-hoc committee under the Director General of the DOI. One of the first activities 
in Nepal was an exchange between irrigation engineers, researchers and farmers in Chitwan in 1998, to talk about ERIP (Sijapati and Prasad, 1998). A decade earlier, such an exchange between engineers and farmers, organized by the study group at Rampur, had sceptically been received by DOI engineers (IIMI, 1988). As Khanal (2003) describes, the spirits among engineers, researchers and farmers was high. It coincided with a time of democratic reforms in Nepal and the dialogue for change was genuine.

In the years that followed, however, many of the new knowledge networks and initiatives lay dormant or collapsed. To illustrate, the study group at Rampur fell apart in 2002 and INPIM/N went dormant around the same time. Clearly, any idea of urgency in the debate on irrigation planning had disappeared in the early 2000s, perhaps because policies had been rewritten (DOI, 2003). Some of the initiatives were given a second life. Notable, INPIM/N was revived in 2008 by Suman Sijapati, a senior engineer in the DOI who had participated in the 1998-meeting in Chitwan on ERIP, when the network was initiated. He explained to me that he was committed to the cause of user participation and saw an opportunity to build a network ${ }^{12}$. In its new life, the network functions mainly as a forum for $\mathrm{DOI}$ engineers and professionals in the donor community. According to its statute, it is still an open network, but a membership fee was introduced for instance, and it was no longer specifically focussing on user participation in irrigation ${ }^{13}$.

In one of the INPIM/N talk shows, on 22 October 2010, the conceptualization of seven new inter-basin river diversion projects of the DOI was discussed (see also DOI, 2011). I attended the event because I was thinking of becoming a member of the network. The talk was given by Madhav Belbase, then a senior engineer in the DOI. The focus of the projects was on "medium and small" rivers within the territory of Nepal. The projects were conceptualized as "national" water supply and diversion projects to secure reliable irrigation in the Tarai as well as hydropower within the boundaries of Nepal. These observations relate to a particular

\footnotetext{
${ }^{12}$ Conversation with Suman Sijapati, 3 January 2011.

${ }^{13}$ E-mail communication with Suman Sijapati, 30 April - 20 June 2017.
} 
professional development experience in Nepal. In the view of DOI engineers, Nepal's modernist aspirations for irrigation and hydropower planning in its international and most suitable rivers (the Karnali, Gandaki and Kosi) have always been frustrated by India (Dhungel and Pun, 2009). These new projects thus held the promise of turning some aspirations into reality. $\mathrm{Mr}$ Belbase presented maps and studies to show what was possible, highlighting points of diversion, potential tunnel alignments and proposed command areas for the projects. One of these maps described the Trishuli Lothar Diversion Project (see Figure 6).

As can be seen, the map is an assemblage of topographic sheets of the surroundings of Chitwan to which two things have been added: 1 ) possible intake points and alignments for a $30 \mathrm{~km}$-long tunnel and 2) an projected command area of 24,500 ha. The map shows existing (basic geographical facts) and planned (intake, canal alignment, command area) information. The map was presented to an audience of about 30 people, who were almost exclusively men, predominantly DOI engineers and some experts of academia and water research institutions. Notably, two senior engineers and regional directors of the DOI were there, as well as three other male engineers who had served as Director General for the department and as water planners for the Water and Energy Commission Secretariat (WECS) (including the above-mentioned Mr Pradhan). The presentation dealt with technical details of the projects (e.g. intake points, tunnel alignments, elevation profiles, design discharge, hydrographs, command areas), transmitting a modernist vision of irrigation development in Nepal in which the projected role of the state was made explicit at the end of the presentation. Mr Belbase proposed that more (engineering) "manpower" was required for the projects. He further explained that Nepal currently lacked an agency for the implementation of multi-purpose projects, and proposed to restructure the Ministry of Irrigation as the custodian of water resources in Nepal, to be named the 'Ministry of Water Resources'. He also suggested establishing a new department under this ministry, the 'Department of Water Resources', for the construction of irrigation projects over 10,000 ha, and the institutionalization of an 'International River Cell' in the WECS to resolve water-sharing issues with India.

Sitting in the audience and being a reader of the presentation, it occurred to me that the maps especially, because of their visual 
aspects, helped to reinvigorate a particular professional experience of modernization in Nepal, expressing aspirations among irrigation engineers for more water powers and building big projects, ideally without the interference of India. More specifically, in the context of an expert culture of masculinity, marked on the occasion by a male audience and a get-togather of engineers, I believe that the maps channelled experience and professional reflexivity in distinct ways. Borrowing the words of Law and Singleton (2000), the maps held that irrigation projects evolve under centralized control; that they need to be managed by experts; that they involve coordinated puzzle-solving; and that they may have setbacks that need to be, and can be, overcome (ibid.: 768-769). The presentation raised a lot of questions in the audience on these subjects, but none of them addressed the 'dispositions' of the maps itself. Notably, nobody related the presentation to more than a decade of research and professional reflection on farmer-managed irrigation and project interventions in Chitwan. More noticeably, on interview, Mr Belbase himself, had elaborated on irrigation interventions in Nepal, discussing setbacks and project failures, and telling me about the skills of farmers in irrigation, especially concerning the Tharu in the Tarai ${ }^{14}$. Hence, he clearly 'knew' about it and I reckon it is lacking in imagination to say that he 'strategically' and fully consciously ignored this knowledge to please his DOI peers and control the irrigation agenda in Nepal. This was only a part of what happened. It seems to me that by using the map of the Trishuli-Lothar project with an audience of (male) irrigation experts, the knowledge of acting as an engineer, in a state of liminal awareness, gained the upper hand and was normalized as 'masculine'.

\section{Conclusion}

In this article, I have shown that maps play an important role when discussing planned development because they are used in a professional culture of 'masculinity' in irrigation. My analysis on maps and the professional network and culture in irrigation has revealed that the association between male engineers in powerful organizations such as the

\footnotetext{
${ }^{14}$ Interview with Madhav Belbase, 26 July 2010.
} 
DOI, the supremacy of science and technology and an experience of modernization, is alive and very much to the forefront. A culture of 'masculinity' continues to mark cultural unity among irrigation engineers and water experts in Nepal. This professional culture has clear global and historical antecedents, particularly rooted in British (Indian) as well as American engineering traditions. In these traditions, maps, male engineers and ideals of science and technology have come to mutually reinforce one other; they are part of the same whole experience in irrigation expert thinking. This implies, for instance, that male and female professionals who seek to create credible roles for themselves (including that of reflection), need to deal with a tradition and experience of expert thinking in irrigation in which a relationship between men, knowledge and power is embodied and normalized as 'masculine'.

This is more easily said than done. My analysis suggests that maps are capable of expressing and structuring an experience of professional reflections and interpretations of reality in liminal ways. Put differently, maps are both 'rational' and 'irrational'. Maps are rational in the sense that they function as technical interpretations and political projects, used by experts in strategic ways to promote (or question) planned development. Maps are irrational in the sense that they are also cultural artefacts, an argument that has not received much scholarly attention to date. Culturally, maps have significance, because they 'bracket' an experience that has an implicit hypothetical past and an anticipated future, connecting it to everyday expert thinking on irrigation planning. The map of the Trishuli Lothar Diversion Project for instance presents Chitwan as being suitable for modern development because it is supposedly empty an idea about the hypothetical past that can be traced back to the late 1940s in Nepal. However, Chitwan is not and never has been empty; it is one of the most intensively farmed districts in Nepal and a lot of its farmland is under irrigation; and its population has increased 14-fold between 1950 and 2010. Nor is Chitwan a national space that is or was solely developed by the state by means of modern technology - an idea about the anticipated future. In Chitwan, farmers have brought more land under irrigation than engineers.

To be more explicit, my analysis suggests that maps can do things that its authors and readers do not fully grasp, disciplining and transforming 
reflexivity at the same time. In other words, maps support myth-making about development in subconscious ways. I believe that the liminality or irrationality of maps is partially located in a high-modernist aesthetic, to use the words of Scott (1998), meaning that they are legible and obtain meaning in irrigation planning, because they apply cartographic conventions and present a world order based on an assumed universal logic of science and technology. My analysis of the use of maps has revealed that modernist ideas in state irrigation planning keep reappearing due partly to their high-modernist aesthetic quality. Even the map of eastern Chitwan, made by the Rampur study group to trigger professional reflexivity, displays modernist aesthetics: it presents Chitwan as being part of a state space, tacitly referring to the idea that the area is suitable for national planning, and it also shows a river network, implicitly corresponding to ideals of hydrological control in irrigation planning. It shows how difficult it is to challenge modernist convictions in development planning in spite of rational debate and professional reflexivity.

\section{Bibliography}

ADAMS A.E., 1982, Chitwan irrigation project. The Lothar sub-project. Interim report - January 1982, Essen, Agrar- und Hydrotechnik GMBH.

ASIAN DEVELOPMENT BANK (ADB), 1972a, Chitwan Valley Development Project, Nepal, Studies, Manila, ADB.

ASIAN DEVELOPMENT BANK (ADB), 1972b, Appraisal of Chitwan Valley Development Project in Nepal, Manila, ADB.

ASIAN DEVELOPMENT BANK (ADB), 1986, PBME [Project Benefit Monitoring and Evaluation] Benchmark survey East Rapti Irrigation Project, Chitwan, Nepal, Manila, ADB.

ASIAN DEVELOPMENT BANK (ADB), 1987, Appraisal of East Rapti Irrigation Project in Nepal, Manila, ADB.

CONNELL R.W., 2005, Masculinities, Second edition, Berkeley and Los Angeles, University of California Press. 
COWARD E.W., KOPPEL B. and SIY R., 1982, Organization as a strategic resource in irrigation development, Honolulu, East West Centre, Resource Systems Institute.

DAHAL N., 1997, “A review of Nepal's first conference on agriculture", Water Nepal, 5(2): 149-164.

DEPARTMENT OF IRRIGATION (DOI), 1990, "Report on inventory of existing farmer managed irrigation systems. East Rapti Irrigation Project. Volume 1 (main report)", Kathmandu, DOI.

DEPARTMENT OF IRRIGATION (DOI), 2003, Irrigation policy of 2003, Kathmandu, DOI.

DEPARTMENT OF IRRIGATION (DOI), 2011, Micro to mega: Irrigation for prosperous Nepal, Proceedings of the National Irrigation Seminar, Kathmandu, Nepal, 13-14 July 2011, Kathmandu, DOI.

DHUNGEL D.N. and PUN S.B. (eds.), 2009, The Nepal-India water relationship: Challenges, Kathmandu, Nepal, Institute for Integrated Development Studies and Dordrecht, Springer.

GYAWALI D., THOMPSON M. and VERWEIJ M. (eds.), 2017, Aid, technology and development. The lessons from Nepal, Abingdon and New York, Routledge.

HARDING S., 2004, "A socially relevant philosophy of science? Resources from standpoint theory's controversiality", Hypatia, 19(1): 25-47.

HILGARTNER S., 2000, Science on stage. Expert advice as public drama, Stanford, California, Stanford University Press.

HIS MAJESTY'S GOVERNMENT OF NEPAL (HMG), 1970, Master plan for irrigation development in Nepal, Kathmandu, HMG.

HIS MAJESTY'S GOVERNMENT OF NEPAL (HMG), 1985, Water resources development in Nepal, Kathmandu, HMG.

HOWARD-GRENVILLE J., GOLDEN-BIDDLE K., IRWIN J. and MAO J., 2011, “Liminality as cultural process for cultural change", Organization Science, 22(2): 522-539.

INTERNATIONAL IRRIGATION MANAGEMENT INSTITUTE (IIMI), 1988, Irrigation management in Nepal: Research papers from a national seminar, Bharatpur, Nepal, 4-6 June 1987, Colombo, IIMI. 
INTERNATIONAL IRRIGATION MANAGEMENT INSTITUTE (IIMI) and WATER ENERGY COMMISSION SECRETARIAT (WECS), 1987, Public intervention in farmermanaged irrigation systems, Colombo, IIMI, Kathmandu, WECS.

JOHN G.St., 2008, Victor Turner and contemporary cultural performance, New York, Bergahn Books.

JYOTI, 1985, Report on the breakage of impellers at Chitwan Irrigation Project, Bombay, Jyoti Limited.

KHANAL P.R., 2003, Engineering participation. The process and outcomes of irrigation management transfer in the Terai of Nepal, Wageningen University Water Resources Series, New Delhi, Orient Longman.

KHATRI-CHHETRI T.B., MISHRA N.K., TIWARI S.N., SHIVAKOTI G.P. and SHUKLA A., 1988, "Lessons from inventory preparation of irrigation systems of Budhi Rapti river, Chitwan, Nepal", in Irrigation management in Nepal: Research papers from a national seminar, Bharatpur, Nepal, 4-6 June 1987, Colombo, Sri Lanka, International Irrigation Management Institute (IIMI): 2-14.

KLINGENSMITH D., 2007, 'One valley and a thousand'. Dams, nationalism and development, New Delhi, Oxford University Press.

LAURIE N., 2005, "Developing development orthodoxy: negotiating masculinities in the water sector", Development and Change, 36(3): 527-549.

LAW J., 2009, "Seeing like a survey", Cultural sociology, 3(2): 239-256.

LAW J. and SINGLETON V., 2000, "Performing technology's stories: On social constructivism, performance and performativity", Technology and Culture, 41(4): 765-775.

LEVINE G., 1992, "The irrigation programme at Cornell University", in DIEMER G. and SLABBERS J. (eds.), Irrigators and engineers. Essays in honour of Lycas Horst, Amsterdam, Thesis Publishers: 25-31.

LEVINE G., 2013, "The search for understanding irrigation - Fifty years of learning", Water Alternatives, 6(2): 259-264.

LIEBRAND J., 2014, "Masculinities among irrigation engineers and water professionals in Nepal", PhD thesis, Wageningen, the Netherlands, Wageningen University, $532 \mathrm{p}$. 
LIEBRAND J. and UDAS P.B., 2017, "Becoming an engineer or a lady engineer: Exploring professional performance and masculinity in Nepal's Department of irrigation", Engineering Studies, 9(2): 120-139.

LILIENTHAL D., 1953, TVA: Democracy on the march, New York, US, Harper and Brothers Publishers.

LYNCH B.D., 1993, "The bureaucratic tradition and women's invisibility in irrigation", Proceedings of the Chacmool conference, Alberta, Canada, University of Calgary and Archaeological Association: 333-342.

MARTIN P.Y., 2001, “'Mobilizing masculinities': Women's experiences of men at work", Organization, 8(4): 587-618.

MARTIN E.D. and YODER R., 1988, "A comparative description of two farmermanaged irrigation systems in Nepal", Irrigation and Drainage systems, 2: 147-172.

MCKENZIE J., 2001, Perform or else: From discipline to performance, London, UK and New York, Routledge.

MIES M., 2014, "The myth of catching-up development", in MIES M. and SHIVA V., Ecofeminism, Second Edition, London and New York, Zed Books: 55-69.

MOSSE D., 2004, "Is good policy unimplementable? Reflections on the ethnography of aid policy and practice", Development and Change, 35(4): 639-671.

MONMONIER M., 1996, How to lie with maps, Second edition, Chicago and London, The university of Chicago press.

MÜLLER-BÖKER U., 1999, The Chitawan Tharus in Southern Nepal: An ethnoecological approach, Stuttgart, Franz Steiner Verlag Stuttgart.

NADER L., 1972, "Up the anthropologist: Perspectives gained from studying up", in Hymes D., Reinventing anthropology, New York, Pantheon Books: 284-311.

NIPPON KOEI, 1989, "Detailed planning report for East Rapti Irrigation Project. Volume 2. Annex A (water balance). Annex B (related letters)", Kathmandu, Nepal, Nippon Koei co. Limited.

OHJA D.P., 1983, "History of land settlement in Nepal Tarai", Contributions to Nepalese studies, 11(1): 21-44.

ONGSAKUL R., RESURRECCION B. and SAJOR E., 2012, "Normalizing masculinities in water bureaucracy in Thailand", International Journal of Public Administration, 35(9): 577-586. 
PANDEY B.B., 1988, Tyas Bakhatko Nepal [Nepal at that time], Volume 1-4, Kathmandu, Self-published.

PRADHAN P., 1989, A comparative study of 21 farmer-managed irrigation systems, Colombo, Sri Lanka, International Irrigation Management Institute.

RAP E., 2006, "The success of a policy model: Irrigation Management Transfer in Mexico", Journal of Development Studies, 42(8): 1301-1324.

RAUCH E., 1954, Report to the government of Nepal on farm enterprises, Rome, Food and Agriculture Organisation.

REUSS M., 2008, "Seeing like an engineer. Water projects and the mediation of the incommensurable", Technology and Culture, 49: 531-546.

RIVERO O. DE, 2001, The myth of development: The non-viable economies of the 21st century, Second edition, Zed Books.

ROTHWELL G.H., 1985, "Report on the sedimentation problems at the Narayani pump irrigation scheme, Chitwan Valley Development Project and proposals for remedial works", Kathmandu, Nepal, Asian Development Bank.

SCHECHNER R., 2006, Performance studies: An introduction, Second edition, New York, US and London, UK, Routledge.

SCOTT J.C., 1998, Seeing like a state. How certain schemes to improve the human condition have failed, New Haven, US and London, UK, Yale University Press.

SHARMA J.L. and MALLA K.B., 1957, Rapti Upatyaka [Rapti Valley], Kantipur, Nepal, Nepal Bharat Maitri Sangh.

SHIVAKOTI G. and OSTROM E. (eds.), 2002, Improving irrigation governance and management in Nepal, Oakland, California, US, Institute for Contemporary Studies.

SHRESTHA M.K., 2001, Readings in Nepalese public administration, Kathmandu, Educational Enterprise.

SHRESTHA N.R., 2009, In the name of development. A reflection on Nepal, Kathmandu, Educational Publishing House.

SHUKLA A., GAJUREL K.P., SHIVAKOTI G., POUDEL R., PANDIT K.N., ADHIKARI K.R., THAPA T.B., SHAKYA S.M., YADAV D.N., JOSHI N.R. and SHRESTHA A.P., 1993, Irrigation resource inventory of East Chitwan, Rampur, Institute of Agriculture and Animal Science. 
SINGH M., LIEBRAND J. and JOSHI D., 2014, "Cultivating 'succes' and 'failure' in policy: Participatory Irrigation Management in Nepal", Development in Practice, 24(2): 155-173.

SIJAPATI S. and PRASAD K.C. (eds.), 1998, Evaluation of irrigation management transfer: Process and performance, Workshop proceedings, Kathmandu, 17-18 September 1998, Kathmandu, Department of Irrigation.

TURNER V., 1987, The anthropology of performance, New York, Performing Arts Journal Publications.

TURNER V. and BRUNER E. (eds.), 1986, The anthropology of experience, Urbana and Chicago, University of Illinois Press.

TURNER V. and TURNER E., 1978, Image and pilgrimage in Christian culture, Oxford, Basil Blackwell.

TURNHOUT E. and BOONMAN-BERSON S., 2011, "Databases, scaling practices, and the globalization of biodiversity", Ecology and Society, 16(1), article 35.

UNITED NATIONS (UN), 1961, Multi-purpose river basin development. Part 2D. Water resources development in Afghanistan, Iran, Republic of Korea and Nepal, Bangkok, Economic Commission for Asia and the Far East, UN.

WATER AND ENERGY COMMISSION SECRETARIAT (WECS), 1995, "Rapid appraisal of Narayani Lift Irrigation System in Chitwan District", Kathmandu, WECS.

WHITEHEAD S.M., 2002, Men and masculinities. Key themes and new directions, Cambridge and Malden, Polity Press.

ZWARTEVEEN M., 2011, "Questioning masculinities in water", Economic and Political weekly, XLVI(18): 40-48.

ZWARTEVEEN M. and LIEBRAND J., 2015, "Performing modernity: The scalar politics of irrigation development in Nepal", in NORMAN E.S., COOK C. and COHEN A. (eds.), Negotiating water governance: Why the politics of scale matter, Surrey, Ashgate Publishers: 263-279. 


\section{Aiviviv}

Janwillem Liebrand is Postdoc Researcher in Water Management Studies

Water Resources Management Group, Wageningen University (The Netherlands)

E-mail : janwillem.liebrand@gmail.com 